\title{
Germany's system of vocational education and training: challenges and modernisation issues
}

\author{
Thomas Deissinger, University of Konstanz/Germany
}

\begin{abstract}
The German education system has recently come under fire with the publication of various international studies on student performance (OECD 2000; 2003). And in the first national 'Education Report' (Bildungsbericht) published in October 2003 (Avenarius et al. 2003), the German ministers of education point out serious deficiencies in the country's school system, with too many drop-outs, too few achievers of higher education entrance qualifications and too little support for students coming from poorer families. However, in a remarkable common press declaration released on 17 September 2003, the ministers of education in Austria, Switzerland and the three southern federal states1 deplored the fact that studies such as the recent OECD paper (OECD 2003) tend to neglect or completely ignore the overall significance of formal apprenticeships, which are not only the most striking common educational feature of the three German-speaking countries, but are also the learning pathway for the 'ordinary school leaver'. The ministers claimed that the 'Dual System' with its apprenticeship focus, offers viable and well-accepted routes into skilled employment and modes of socialisation without being part of the formal education system, and they eventually appealed to the OECD to 'accept and investigate the status of vocational education'.

This debate, which is also fostered by the announcement of the German Federal Government's determination to substantially increase the number of students entering higher education, brings into focus the tendency in Germany to stick to established modes and practices by valueing 'continuance of tradition' (Phillips 1995, p. 61). It also throws new light
\end{abstract}


on both the firmly rooted three-tier approach in the country's secondary school system (Ertl 2000) and on the country's vocational pathways that have for decades been considered to be reliable and successful, especially in international terms. One of the outstanding examples of a clear disinclination to reform is the Dual System of apprenticeship training. Although it may be argued that Germany's high educational participation in post-compulsory secondary education is mainly due to the apprenticeship system (83\% of 25-64 year-olds have reached this level), 2 both the apprenticeship system and the full-time vocational schools now face challenges that have a national and an international dimension. Besides globalisation and the changing nature of industrial work organisation (Baethge \& Baethge-Kinsky, 1998), Germany's re-unification and a slackening economy continue to put strain on the national budget, on the labour market and on the education and training system (Miller Idriss 2002). Against this background, modernisation issues have emerged which touch the relationship between full-time and part-time VET as well as the nature of apprenticeships.

\section{Characteristics of the German system of vocational education and training}

The Dual System of initial vocational training in Germany owes much of its reputation to the fact that it has remained one of the most frequently (though not necessarily successfully) copied training systems in the world (Arnold 1985; Greinert 2001). Furthermore, it is often quoted when it comes to working out contrasts with other countries, including Australia (eg Deissinger 2001c; 2002b; Keating et al. 2002; Coffey \& Rhodes 2002; Burke \& Reuling 2002). Obviously there seems to exist a number of major discrepancies between what may be called the 'Anglo-Saxon model of VET' as realised in the UK or Australia, and the 'Dual System' in Germany, with its long-standing apprenticeship tradition (Deissinger 2002b).

\section{Working principles of apprenticeships in the dual system}

Although the combination of learning and work within the bounds of a dualism of 'learning sites' (part-time vocational school and training company) is normally considered to be the quintessential facet of the German system of vocational training (Greinert 1994), its working principles are more complex. Its crucial philosophy is vocationalism which means that training is workplace led and predominantly practical, stressing the importance of work experience during the training period. It encompasses a holistic set of competences defined 'around the workplace' (Harney 
1985; Deissinger 1998) and based on national qualification standards according to the 1969 Vocational Training Act or Berufsbildungsgesetz (Deissinger 1996; Raggatt 1988). In terms of its 'macro-structure', the Dual System is determined by the state's active role that secures occupational standards and conditions of skilled apprenticeship. Unlike other countries that have apprenticeships as part of their training systems, the law in Germany stipulates what makes an apprenticeship (Ryan 2001, p. 133) and training thus becomes legally enforceable while at the same time being relevant to the skill demands of employers (Raggatt 1988).

Against this background, the German 'training culture' (Brown \& Evans 1994) is based on the notion that vocational training should not only be a specific form of employment but also an educational issue. Therefore, under the federal state education acts, it is mandatory for school-leavers under the age of eighteen who are not in higher or further education to attend the local part-time vocational school on a sandwich or day-release basis (making the system a 'dual' system). Lessons in the vocational school include vocational subjects relevant to the respective occupation, but also general studies such as German, English or Sports. Georg Kerschensteiner (1854-1932) is widely held to be the father of the German vocational school, and his conviction that 'education for the ordinary man and woman must be woven into the practical work of life' (Higginson 1990, p. 248) clearly shaped not just the dualism of the system but also underlined the idea of Beruf or vocation, which in Kerschensteiner's eyes stood for the major route by which an individual ought to achieve his or her personal development. Such an ideal, without its vocational bias, refers back to Humboldt's educational theory developed at the beginning of the $19^{\text {th }}$ century which was then associated with the concept of non-utilitarian academic education (Bildung) of the upper classes (Blankertz 1979; Blankertz 1982, pp. 89 ff.; Zabeck 1975a).

However, the most interesting aspect of Germany's Dual System, is the fact that, on the company side, the state's function is restricted to securing quality standards in a predominantly formal manner. Besides public institutions such as the Federal Ministry of Education and Research (BMBF), the Federal Institute of Vocational Training (BiBB), and the various federal state ministries of education, reliable participation of firms is one of the key requirements for the successful working of vocational training. It may be argued that the training market in Germany 'has the character of a suppliers' market' (Greinert 1994, p. 80; NCVER 2001, p. 38). Once a training contract has been signed the firm accepts the principal financial responsibility for the training process including all direct and indirect costs such as training personnel, machinery, training administration and social insurance contributions. The system being funded principally by employers reflects the principle that companies provide training opportunities on a voluntary basis. While the overall training participation quota in Germany is almost $30 \%$ in the old and $27 \%$ in the new federal states (2001), at $91 \%$ participation, big companies train to a very large extent. In 2000, companies invested 
nearly 28 billion in the Dual System, with an average training outlay per apprentice currently rated at 16,435 p.a. (Beicht \& Walden 2002). Therefore, the cost argument is one of the most important reasons companies give for not offering more training opportunities in the apprenticeship system.

Although the training provided within businesses is essential, it is not designed to lead to over-specialised training since priority is given to 'broad-based knowledge and the acquisition of basic techniques' (Géhin \& Méhaut 1995, p. 65). For this purpose, the administrative and organisational contribution of the chambers is indispensable. The Vocational Training Act (Deissinger 1996) places vocational training in the hands of firms and chambers and thus emphasises the principle of self-government (Zabeck 1975b). The 'competent authorities' - as the chambers are named by law - monitor in-company training, support training companies and hold exams for journeymen, skilled industrial workers, commercial clerks and masters.

Thus, the elements involved in the German training system can be summarised as follows:

- Vocationalism linked to the notion of Beruf

- Formal state quality control

- Dualism of learning sites

- Compulsory attendance at the vocational part-time school

- Commitment and involvement of chambers and companies.

Clearly the German apprenticeship system is not only the current 'centrepiece of vocational education and training in the Federal Republic' (Raggatt 1988, p. 166) but it goes back to strong cultural foundations, including the long-standing tradition of craft training which actually dates back to the Middle Ages (NCVER 2001). Compared with other European countries - especially Britain (Deissinger 1994) - the genesis of the modern vocational training system was the outcome of crucial state activities to revitalise the ancient craft system. The system became a 'dual' training system during the first two decades of the 20th century when vocational part-time schools replaced the continuation schools (although compulsion was only enforced in 1938) to accompany apprenticeships and to give young people education 'through the vocation'. The chambers of industry and commerce began holding examinations for industrial workers around the middle of the 1920s, based on training recommendations (Muth 1985; Schütte 1992, pp. 79 ff.). Since then, industrial as well as commercial training has been subject to the corporatist framework associated with the craft training tradition and is an economically relevant part of the employment sector.

In comparing German dual apprenticeships with modern apprenticeships in the UK, Ryan (2001, p. 137) refers to the key differences between the two countries and indicates that there may be some 'overregulation' of the German system: 
... the contrast to Germany is sharp. There is no equivalent of Germany's minimum training periods, mandatory part-time courses at the Berufsschule, and compulsory general education. More generally, while in continental Europe apprenticeship is integrated into the national education system, straddling the worlds of education and training, British apprenticeship is located firmly on the training side. One potential benefit of British arrangements is greater adaptability and flexibility of training content in response to economic change. The time that it takes to revise apprenticeship curricula in Germany is well known

Apprenticeships are offered to young people in a range of 350 recognised skilled occupations and, although declining since the mid 1980s (Reinberg \& Hummel 2001, p.24f.), the system still takes in some 60\% of 15-19 year old school leavers on their way to independent adulthood, including those with a higher education entrance qualification (Abitur), who make up around 15\% of all apprentices. Unlike in most other European countries, with the exception of Austria and Switzerland, apprenticeships in Germany exist in nearly all branches of the economy, including the professions and parts of the civil service.

Complying with the craft tradition, small and medium-sized companies are major suppliers of training opportunities (Deissinger 2001b). In 1953, the Craft Regulation Act (Handwerksordnung) encapsulated earlier legislation dating back to the late 19th century (Deissinger 1994) by making provisions affecting vocational training in general and the taking on and instruction of apprentices in particular (Knörr 1996, pp.194 ff.). It defined a list of 111 trades as craft occupations (Benner 1987, pp. $281 \mathrm{f}$.). This law has been in existence ever since as a parallel code to the Vocational Training Act. There are no crucial deviations from the principles underlying the general framework typical of apprenticeship training in Germany with the exception of a 'full-scale proof of competence'. However, this is only indirectly linked to apprenticeships as it mainly affects the right to establish a craft business (for details see Knörr 1996). This is currently at stake with the German government's intention to liberalise labour markets in order to comply with European law³.

Despite being more or less ignored in the context of international school performance studies, apprenticeships have to be seen as part of the educational system, and in Germany, Austria and Switzerland (Gruber 2001; Gonon 2001), they still provide respected pathways into the world of work for the majority of school leavers. In Germany, neither the expansion of full-time vocational courses in schools nor the ideologically motivated critique of the Dual System during the19960s and 1970s put the system at stake despite it being branded as a system of exploitation by the 'emancipatory' educational movement (Kell 2001; Deissinger 1998, pp. 25 ff.; Baethge 1983). The accusation of the time against apprenticeship training that it was a 'dead end road' is not valid these days since it is this vocational education 
system as a whole that opens up various pathways leading to general qualifications (eg the Abitur, ie the general higher education entrance qualification) or vocational qualifications (eg technician qualifications in the vocational special training schools), and helps young people to progress. The following chart illustrates these trajectories within the German system (in the case of the school leaver coming from the lower secondary school).

Table 1

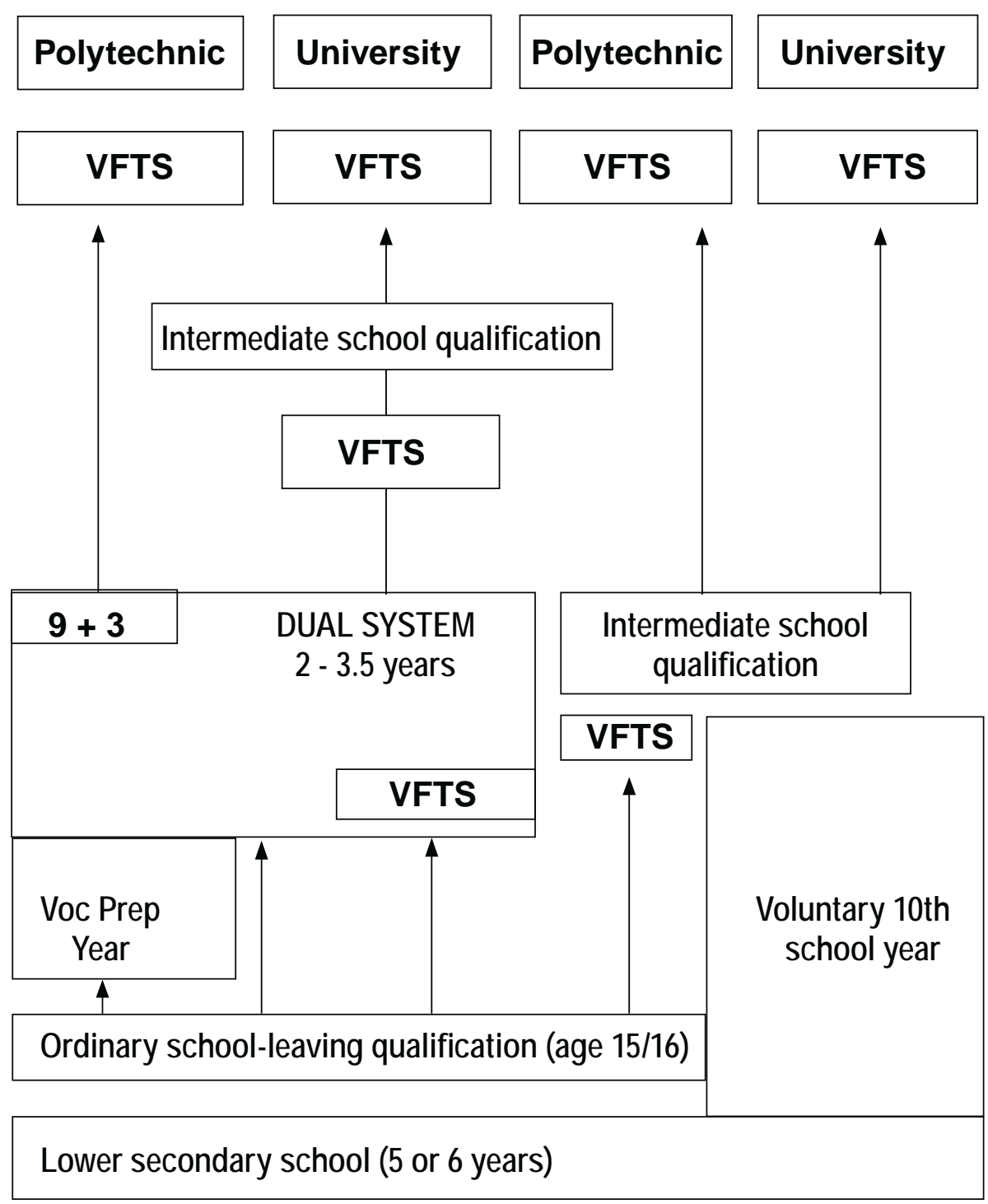




\section{Functional diversity of full-time vocational schools}

In terms of student numbers, the Dual System participants outweigh the numbers in full-time vocational schools. Out of nearly 2.7 million students in non-academic VET in 2000, 1.8 million were undergoing an apprenticeship in the Dual System. 415,000 attended an ordinary vocational full-time school (Berufsfachschule) with the option of entry level vocational training in specified occupational areas, such as nursing or physiotherapy (depending on the type of school and the federal state). However, the number of students attending three of the major sub-types in full-time VET (vocational foundation year; vocational preparation courses; ordinary vocational full-time schools) increased between 1993 and 2001 from 363,351 to 541,676. It may be argued that there is an empirical interaction between this rise and the situation in the training market. As companies express doubts about the future demand for skilled employees and complain about the lack of training maturity among school leavers, the latter have to search for alternative pathways, a phenomenon which is aggravated by the regional and occupational imbalances in the training market, including the difficult situation in eastern Germany. Therefore, the numbers of students entering higher education and the influx into vocational full-time schools have increased in recent years and are likely to rise further in the forthcoming years (for all figures see Federal Ministry of Education and Research 2003) ${ }^{4}$.

Besides what may be called the 'parking function' of vocational schools due to training market restraints (Reinberg \& Hummel 2001, p. 28), the relationship between the Dual System and the various subtypes of school-based vocational education and training systems under the auspices of the federal states appears to be ambivalent. This means that vocational schools basically serve three functions, depending on the course and the institution offering it (Feller 2000; Reinisch 2001; Kell 1996; Deissinger \& Ruf 2003):

- Vocational preparation (mostly one to two years) which means enabling young people to go for an apprenticeship by improving their stakes in the training market

- $\quad$ Further education (mostly two to three years) which means leading young people to achieve a higher school qualification level (including, eg, the Abitur)

- Vocational training (mostly two to three years) which means leading young people to achieve a portable occupational qualification outside the Dual System

In terms of vocational training, school-based VET is considered complex since vocational full-time schools may offer courses leading to qualifications either within or outside the scope of the Vocational Training Act. In addition, some schools deliver entry-level training based on specialised federal regulations, such as in the area of health occupations, whilst the ordinary full-time vocational schools (Berufsfachschulen) provide for a wide range of students and aspirations. There are schools that offer 
a full occupational qualification and there are institutions that only partly focus on occupation-relevant competencies, as they deliver either school qualifications (such as the intermediate secondary school leaving certificate) or concentrate on vocational preparation (Feller 2000). One of the biggest problems is the lack of acceptance from the labour market for most vocational qualifications obtained in school-based fulltime courses against the background of a long established Dual System (Euler 2000).

Owing to space constraints in this paper it is not possible to discuss these functions in more depth. Therefore the Berufskolleg (vocational college) in the federal state of Baden-Württembergha beens chosen to illustrate the ambivalence of full-time vocational education in Germany. The vocational college is a school that can be attended by students with a medium-level school leaving qualification (mittlerer Bildungsabschluss), which may be obtained in a vocational full-time school (for example, in a Berufsfachschule) or in general education (in the Gymnasium or the Realschule). The following table shows where the Berufskolleg (BK) is located within the school system of Baden-Württemberg:

Table 2: The location of Berufskolleg (BK) within the vocational schools in Baden-Württemberg

BRANCHES

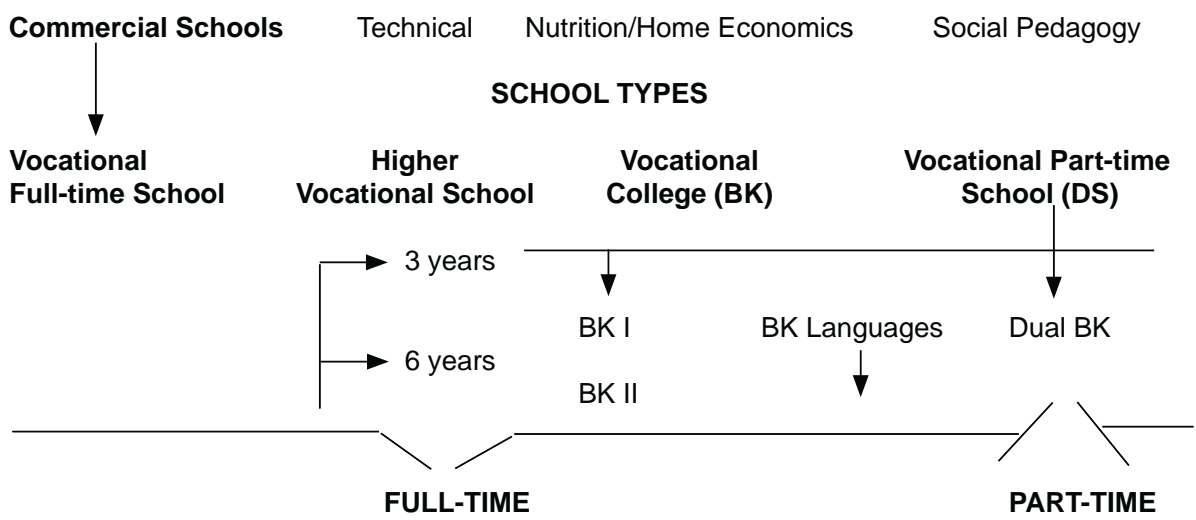

Entry requirements:

- Vocational Full-time School: lower secondary education (year 9 / Hauptschule)

- Higher Vocational School: intermediate secondary education (year 10 / Realschule or Vocational Full-time School)

- Vocational College: intermediate secondary education (year 10 / Realschule or Vocational Full-time School)

- Vocational Part-time School in the Dual System: lower secondary education (year 9 / Hauptschule) 
BK courses hold the following options, although their dominant function (with the exception of the BK I and the Dual BK) is now to provide students with a polytechnic entrance qualification in addition to their occupational qualification, a concept that is likely to emerge as the regular model in the future following the growing tendency of German school leavers to strive for higher education ${ }^{5}$ :

- $\quad$ BK I - one year (preparation for Dual System)

- $\quad$ BK I/II - two years with the following options: - assistant qualification (conventional type)

- assistant qualification + polytechnic entrance qualification

- $\quad$ BK Languages (BK-F) - two years

- $\quad$ BK Business Information Management - two years

- $\quad$ BK with practice firm - two years

- $\quad$ BK-FH (part-time access studies out of employment leading only to polytechnic entrance qualification)

- $\quad$ Dual BK (special part-time school for apprentices with a grammar school leaving qualification) - two years]

The fact that apprenticeship shortages and training market imbalances are likely to persist is putting strain onto school-based vocational education and training in a specific way. Policy-makers continually claim that the apprenticeship system has to be strengthened, while at the same time insisting that progression into higher education ought to be pushed. Thus, the 'multi-functionality' of vocational schools has to be seen in a new light. Their present function is strongly linked to entry into further or higher education rather than to the purpose of delivering labour market qualifications, but as schools have to serve an increasingly diverse clientele, teachers in future are likely to be faced with a wide range of students with different aspirations. The BadenWürttemberg Ministry of Education is currently intent on finding ways to increase the labour-market relevance of school-based qualifications, this particularlt affects the vocational colleges and the acceptance and portability of the assistant qualification. One of the didactical tools which is supposed to help achieve this goal is the ongoing implementation of practice firms in each of the state's vocational colleges (Deissinger $\&$ Ruf 2003). This could eventually result in a new policy to strengthen the vocational qualification function of schools in general and cope with the growing number of school leavers who want to step into VET as a pathway into higher eduation.

\section{Problem issues and challenges}

Looking at the working principles of the Dual System, especially the vocational principle as its 'defining element' (Miller Idriss 2002, p. 473), it becomes evident 
that vocational training is embedded in a 'stress field' between private interests and private commitment in the field of apprenticeships on the one hand, and public and state interference in order to secure as many training opportunities as possible and maintain standards of training outcomes on the other (Kell 1999). In the past decade, the German Dual System has been increasingly criticised for its obsolescence in the face of a rapidly changing economic and social environment (e.g. Geissler 1991). Moreover, the serious situation in the training market, especially in the east of Germany, has emerged as an important issue of public concern. In 2002, the task of providing all applicants with a training place was again associated with major challenges. At 572,227, the number of new training contracts was down 42,000 on the previous year and, decreasing by $6.8 \%$, reached an unexpectedly low level. For the training year that began in autumn 2003, the Federal Labour Office reported an $8.1 \%$ decrease in available training places in the western states against the preceding year which means that by early October 2003 there were still 35,000 young people seeking an apprenticeship place ${ }^{6}$. Both the industrial and the craft sector, being the two strongholds of training provision, suffered major declines.

Table 3: Distribution of apprentices and changes (re. numbers) to previous year (new contracts) according to area of employment/training sector (2002) [western Germany]

\begin{tabular}{|l|l|l|}
\hline & share in 2002 & change on 2001 \\
\hline Industry and trade & $53.0 \%$ & $-8.3 \%$ \\
\hline Craft trades & $31.2 \%$ & $-7.0 \%$ \\
\hline Professions & $10.4 \%$ & $-1.5 \%$ \\
\hline Public sector & $2.5 \%$ & $-2.5 \%$ \\
\hline Agriculture & $2.1 \%$ & $+2.9 \%$ \\
\hline Domestic services & $0.7 \%$ & $-3.9 \%$ \\
\hline
\end{tabular}


Table 4: Distribution of apprentices and changes (re. numbers) to previous year (new contracts) according to area of employment/training sector (2002) [eastern Germany]

\begin{tabular}{|l|l|l|}
\hline & share in $\mathbf{2 0 0 2}$ & change on $\mathbf{2 0 0 1}$ \\
\hline Industry and trade & $59.3 \%$ & $-5.8 \%$ \\
\hline Craft sector & $27.6 \%$ & $-10.5 \%$ \\
\hline Professions & $5.4 \%$ & $-5.0 \%$ \\
\hline Public sector & $2.8 \%$ & $-8.1 \%$ \\
\hline Agriculture & $3.6 \%$ & $+0.6 \%$ \\
\hline Domestic services & $1.2 \%$ & $-4.0 \%$ \\
\hline
\end{tabular}

Accordint to the Federal Ministry of Education and Research (2003) the following factors were responsible for the serious situation in the training market:

- the weak economy

- insecurities about the future demand for skilled employees

- lack of training maturity among school leavers

- regional and occupational imbalances in the training market.

The Federal Goverment has made it clear it considers the Dual System is in a critical state and has announced a number of compensating measures to relieve the unstable situation in the training market. Although these measures are partly outside the German training tradition, they are nevertheless seen in the context of the high respect that has always been paid to vocational training. In the 2003 Federal Training Report (Federal Ministry of Education and Research 2003, p. 2) it is argued that...

(these) challenges call for continued and increased initiatives aiming at the qualitative improvement of the vocational education and training of all those concerned. Sound and broad-based vocational education and training of all young people is, and will remain, one of the most important cornerstones of the ability of industry and society alike to meet future challenges.

It has also become obvious (see Table 4) that the new federal states (eastern Germany) are particularly affected as the craft tradition there is not as strong as in the west, and compensation coming from public funds does not match deficiencies in the private sector. Nevertheless, in October 2003 the Federal Government was hoping to reduce the number of 'unprovided applicants' in the eastern states from 12,000 to 5,500 by offering publicly financed alternatives to school leavers. At the same 
time, government does not want the system to change fundamentally, but wants to see modernisation taking place within its boundaries. Therefore, the focus remains primarily on employers as major providers of apprenticeship training.

By providing an appropriate general framework, the Federal Government's future vocational education and training policy will focus, among other things, on supporting industry in its efforts to supply a number of training places that matches the demand. This framework will include both a reform of vocational education and training law and an economic policy furthering small and mediumsized enterprises. In addition to economic recovery, such a policy can play a major role in this situation. At the same time, reforms started during the past legislative period will be vigorously pursued; these reforms were designed to modernise the initial and continuing vocational education and training system, make it more flexible and open it up at the international level.

(Federal Ministry of Education and Research 2003, p. 2)

Despite this support for privately funded apprenticeships, the government has been forced to subsidise training schemes created for the purpose of establishing alternative ways of vocational preparation and integration, due to the fragile economic framework in eastern Germany. In 1998, against a background of rising youth unemployment, the JUMP programme (JUgend Mit Perspektive - which means Youth with Perspectives) was initiated with the aim of bringing young people into training beyond the regular training market (Bundesministerium für Arbeit und Sozialordnung \& Bundesministerium für Bildung und Forschung 1999). In 2002, special training place programs for eastern Germany led to 14,000 additional training opportunities, mostly provided by external providers (Bildungsträger) in co-operation with local employers. 138,000 young people joined the Immediate Action Program for Young People which was developed to create regular training places.

The Federal Training Report puts the number of schemes launched in 2002 at 196 and the number of newly created apprenticeships at 10,000. Since 1999, a total of 60,259 training places have been created under the various schemes using public money. This illustrates that the Dual System in its traditional form featuring employers as training providers and funders of apprenticeships can no longer be seen as the only non-academic route into employment. The growing importance of state involvement within the system is also underlined by the rising number of attendees of schoolbased vocational preparation courses as well as full-time students in vocational education and training, of whom in $200250 \%$ attended courses leading to vocational qualifications considered to be portable on the labour market (Federal Ministry of Education and Research 2003, pp. 8 f.). 
To address the training market problem more clearly, the federal government has recently introduced the concept of training place developers (Ausbildungsplatzentwi $c k l e r$ ) in order to secure the long-term provision of training places and detach it from the contingencies of the labour market. This includes helping companies cope with the administrative work involved in an apprenticeship, establish co-operation with vocational schools, and set up company-specific training plans. With another program called 'STARegio', regional joint training provision is to be promoted by companies pooling together in order to enable young people to achieve all the competences within a given occupational training scheme ${ }^{7}$. Moreover, the introduction of a training levy seems to be likely as the two ruling parties in the federal government (Social Democrats and Greens) have in principal agreed to this principle. This could mean that companies not engaged in training would have to contribute $1 \%$ of their payroll into a fund out of which additional training places could be created ${ }^{8}$. This move has to be seen against the fact that at the end of September 2003, only 6,500 school leavers could be provided with a training opportunity ${ }^{9}$, leaving 35,000 school leavers still searching. German employers, however, have previously refused such a move, fearing that this could eventually lead to even fewer training places ${ }^{10}$.

\section{Modernisation moves}

In its White Paper published in 1993 (European Commission 1993) the European Commission pointed out that lifelong learning should become 'the overall objective to which the national educational communities can make their own contributions'. Two years later, in the White Paper on Teaching and training - Towards the learning society (European Commission, 1995), the concept of lifelong learning became associated with the idea of a 'personal skills card designed to enable every European citizen to acquire and document new knowledge and skills in various formal and informal learning environments. Against this background, the strong cultural focus on apprenticeships in Germany carries some obvious ambivalence which is at least indirectly linked to the vocational principle:

- $\quad$ On the one hand, apprenticeship qualifications represent entry-level qualifications which help people become competent for a given occupation. Strictly speaking, this implies that these skills should last for the whole working life.

- $\quad$ On the other hand, apprenticeship qualifications are the basis of all further training activities, both informal company-based training and training given in formal learning environments (eg master craftsman or technician courses). This implies that skills development within companies' human resource development normally begins at a comparatively high level. 
The fact that the Dual System is still the major, though not the exclusive, focus of vocational education and training policy, implies that modernisation is mainly happening within the existing system, a phenomenom that may be called process innovation or internal modernisation. Rather than undertaking radical reform of the system, internal modernisation means that reforms take place within the existing structural environment of a vocational education and training system using its institutions and organisational patterns. With respect to the apprenticeship system, two concepts of such a 'mild strategy' can be identified - (i) the ongoing modernisation of training courses, and (ii) the implementation of specific features of modularisation.

\section{Modernisation of training schemes}

The policy of modernisation tries to take account of the need to integrate new workplace developments into the existing system of vocational training. 2003 saw the emergence of seven new training occupations and 21 schemes underwent revision procedures ${ }^{11}$. Moves towards a more up-to-date training system try to link the traditional notion of vocationalism associated with the German terms Berufsprinzip or Beruflichkeit (Deissinger 1998) with the changing patterns of work organisation and the emergence of new technologies in trade and industry produced by the growing importance of data processing and the expanding scope of communication technology.

The general principles underlying the revision of training schemes beginning in the late 1980s may be summarised as follows (Schelten 1989, pp. 89 ff.; Steeger 1999, pp. 1 ff.; Sander 1998):

- $\quad$ Training content should to be specified within the context of a clearly defined course which offers the opportunity to develop skills on a broad scale.

- $\quad$ Training schemes should lead to competencies which allow employees to plan, execute and assess their work on their own.

- $\quad$ Flexibility requirements for employers and employees should be taken into account in the development of training occupations.

- $\quad$ Lifelong learning should become one of the cornerstones of vocational training policy by opening up opportunities to re-train due to the changing nature of work environments and technologies.

- $\quad$ Training should correspond with the growing importance of communication skills, key or generic competencies, as well as customer orientation in the working process.

Since the passing of the Vocational Training Act in 1969, most training ordinances have undergone some kind of revision or re-definition while new schemes have been created (Deissinger 2001a). These occupations now cover more than $90 \%$ of 
all apprenticeships in the Dual System. For example, in 199749 occupations were either newly created or received some kind of fundamental re-definition of training objectives and training contents. Major innovations include the substantial redefinition and re-organisation of training schemes in the metal and electrical trades in the late 1980s, but also two popular commercial occupations (i.e. office clerk and communications clerk) which were given a new face at the beginning of the 1990s (Stiller 1992; Reinisch 1993). One of the most significant modernisation projects gave birth to the family of IT occupations (introduced in 1997) which took the Dual System beyond its craft-based past (Müller et al. 1997; Petersen \& Wehmeyer 2000). These four occupations link modern information technology and data processing with technical and commercial applications. From an educational point of view, training for these occupations also implies new ways of teaching methodology and complex learning arrangements (Pätzold 1990) but certainly makes them more demanding than conventional industrial or craft occupations. Therefore, these occupations are typical pathways for school leavers from the grammar schools, or from higher vocational schools, or even for drop-outs from universities (Dostal 2002, p. 151 f.) ${ }^{12}$.

As early as 1987, some of the major craft occupations also underwent re-organisation in line with related industrial schemes in the metal and electrical trades. This modernisation may be seen as an attempt to give the conservatively structured craft sector a more up-dated outlook in the face of globalisation and internationalisation of the economy (Borch et al. 1991; Klein 1989). The structural features of this redefinition of training schemes may be summarised as follows (Schelten 1991, pp. 89 ff. $)^{13}$ :

- Occupations no longer exist independently as 'mono-occupations', but are grouped together in a family of related training schemes.

- Occupations are trained for three and a half years (formerly three years).

- A family of occupations has a common basic training year where the foundations are laid for specialisation and differentiation.

- $\quad$ Specialisation in the second half of the second year normally refers to a specific occupation while in the last one and a half years differentiation occurs within each single occupation.

Another major innovation may be seen in the re-definition of training schemes underlying apprenticeship for office clerks, one of the few commercial training profiles also used in the craft sector and a typical example of a small business commercial qualification (Reinisch 1993, Buschfeld et al. 1999, pp. 35 f.). Here key competencies (Schlüsselqualifikationen) are supposed to stretch over the whole training period by adding those qualifications common to related occupations (in this case the communications clerk). Such qualifications are defined as fundamental qualifications (Sockelqualifikationen), and they are supposed to become less relevant in the training syllabus with the years of training and make room for occupationspecific skills. In the context of the new IT occupations they are called core 
qualifications (Kernqualifikationen). This principle appears to be dominant in most of the newly created schemes which include typical 'mono occupations' as well as families of related occupations.

\section{Modularisation}

Although some of the newer training occupations now allow for more specialisation and flexibility (like those in the metal and electrical trades and also in the IT sector), they only make tentative use of modularisation. This makes access to different levels within the qualification process virtually impossible, but clarifies the distinguishing features between the German concept of Beruf and the philosophy of competencebased education and training typical for Anglo-Saxon countries such as Australia and Britain (Misko 1999; Wolf 1995). While the move towards more flexible training schemes has become associated with expectations that this might eventually lead to more training places and more efficient training arrangements in companies, some have voiced concern that the scope for reform is rather limited since different cultures use different meanings of modularisation (Deissinger 2002a; Sloane 1998; Pilz 1999). In Germany, the debate circled for quite a while around the question of whether modular principles are generally compatible with the organisational features of the Dual System, but there is now a general understanding that reforms should take place within the system.

From an institutional and didactical point of view, three ways of modularisation may be distinguished (Deissinger 2002a):

- Disintegration concept: This means dissolving occupational patterns by establishing a modular system with variable access opportunities and flexible levels of qualification standards. With their similar certification systems, England and Scotland have established a competence approach linked to modularisable qualifications that are defined by employers and assessed in the workplace (Hodgson \& Spours 1997; Pilz 1999). This system has been designed to substitute traditional qualifications and to bridge the spheres of general and vocational education.

- Differentiation concept: Implanting modules within training schemes as didactical units does not necessarily mean giving up occupational skill formation (Euler 1998, pp. 96 ff.). Vocational profiles with elective modules (such as the IT occupations) offer more flexibility in terms of training content but remain portable in a conventional way since they still stand for holistic sets of competences. The advantageous effects of such a 'mild' strategy of modularisation may be seen in adapting the existing training system to technological developments more easily and more quickly. 
- $\quad$ Supplementation concept: Increasing the number of formal levels at which vocational qualifications are obtained is a third way to modularise a training system. Providing more flexibility to the different levels of educational achievements of young people seems, at least at first glance, more agreeable among interest groups involved in German vocational training policy than the disintegration approach. This includes providing opportunities for more able learners within uniform training schemes to attain additional formal qualifications (Pahl \& Rach 1999). At the other end of the qualification ladder, differentiation could lead to special training courses for weaker learners, including new stage-structured training schemes which the Vocational Training Act actually allows for ${ }^{14}$.

In its 2003 Federal Training Report, the federal government refers to modules in four areas of developing and modernising the existing VET system (Federal Ministry of Education and Research 2003, p. 14 ff.):

- Some of the new training occupations, including the abovementioned IT courses, already provide for forms of specialisation in the third training year by offering employers elective modules to choose from.

- The federal government wants to link vocational preparation courses that are becoming more important in the wake of a shrinking training market, more closely with initial training in the apprenticeship system.

- It is intended to develop new ways and means to enable young people to use credits from courses in full-time vocational schools for their final apprenticeship examination ${ }^{15}$.

- Modernisation initiatives also pick up the idea of establishing new forms of assessments, such as the 'extended' or 'stretched' final examination which allows for credit transferability of interim examinations to the chamber examination.

The government has announced that it wants to initiate a revision of the Vocational Training Act, picking up the above-mentioned reform options (Federal Ministry of Education and Research, 2003, p. 18). At the same time, policy seems to be heading towards creating boundaries between different areas of VET more permeable which implies that the overall importance of the Dual System could become less weighty in future years without giving up the belief that training in companies still has a viable and relevant route into employment for the majority of school leavers. 


\section{Conclusion}

Despite modernisation expectations, the features of the Dual System still appear to be unchanged and modernisation occurs 'internally' rather than through a change of paradigm or underlying principles. However, challenges have turned out to be less solvable than in the past, especially when it comes to the volatile training market with its dependence on the state of the national economy. As well, there are challenges caused by alternative approaches to VET such as 'vocational academies' (Deissinger 2000) or the likely expansion of 'vocationalised' university or polytechnic courses with the projected reform of university systems within the European Union. Apart from that, the Dual System still does not build bridges to the academic world, for example, through double qualifications that are prominent in the VET systems of France, Austria and even Switzerland (Deissinger 2001d; Gruber 2001; Gonon 2001).

As to the future perspectives of the Dual System, another crucial question might be whether the rapidly expanding services sector, including data processing and innovative customer-orientated services, will be willing or able to follow its 'philosophy' of training, especially the vocational principle. The future appeal of apprenticeships will also depend on other nations' experiences with more 'open' or 'market-oriented' approaches to VET and their functional links, both in quantitative and in qualitative terms, with the national and international labour markets. Whilstever the prime concern of vocational training policy in Germany remains on initial training, there can be no doubt that the training market will remain the biggest challenge. It is also obvious that the overall decline in apprenticeship intakes over recent years is due to the supply side of the training market and not to young people's lack of enthusiasm for the Dual System in general (Reinberg \& Hummel 2001, p. 25). After years of substantial support from employers, Germany now seems to have joined those countries that are trying to convince the private sector of the benefits of skill formation.

Professor Dr. Thomas Dessinger is Professor of Business Education at the University of Konstanz, Germany.

\section{Endnotes}

$1 \quad$ See Gemeinsame Presseerklärung der Schweizerischen Konferenz der kantonalen Erziehungsdirektoren, der Länder Österreich, Baden-Württemberg, Hessen und Bayern zur OECD-Studie „Bildung auf einen Blick“ (Pressemitteilung des bayerischen Kultusministeriums, No. 288, 17 September 2003).

2 See Gemeinsame Presseerklärung von BMBF und KMK, 16 September 2003 (www.bmbf.de/presse01/934.html). 
3 The new law was due to be passed in January 2004, and was expected to comprise two major changes to labour regulation in the craft sector. Firstly, the number of craft occupations was to be cut down by taking out 'simple working activities' which could be learnt within a time span of three months; secondly, the master craftsman certificate would only be demanded as an entry prerequisite for establishing a business in 29 occupations associated with 'danger prone' activities (see Südkurier, No. 238, 15 October 2003).

$4 \quad$ Between 1998 and 2002 the share of school leavers entering higher education rose from $28 \%$ to $35 \%$, which is still below the OECD average of $47 \%$. - See Gemeinsame Presseerklärung von BMBF und KMK, 16 September 2003 (www.bmbf.de/presse01/ 934.html).

5 See www.vlw-bw.de/wirtschaftplus/wplus/ausgabe_04_2003/weiter_bk.htm.

$6 \quad$ See Federal Ministry of Education and Research, Pressemitteilung 182/2003, 9 October 2003 (Pressedienst@bmbf.bund.de).

$7 \quad$ See Federal Ministry of Education and Research, Pressemitteilung 195/2003, 21 October 2003 (Pressedienst@bmbf.bund.de).

8 See Südkurier, No. 256, 6 November 2003

9 See Federal Ministry of Education and Research, Pressemitteilung 205/2003, 6 November 2003 (Pressedienst@bmbf.bund.de).

10 See Curatorium of the German Economy for Vocational Training, Pressemitteilung, 20 November 2003 (www.kwb-berufsbildung.de/frontend.phb3?id=93).

11 Among the new occupations are the "car mechatronic" and the "investment clerk". Both new technologies and the growing demand for specialisation may be seen as the triggering factors for the creation of such occupations (see www.bibb.de)

12 The number of trainees in the IT occupations currently stands at 77,000 (Federal Ministry of Education and Research 2003, p. 12).

13 The industrial metal and electrical occupations are currently undergoing revision with the new training schemes to be decreed in 2004 (Zedler 2002; see also www.bibb.de).

14 German employers in general favour both higher degrees of specialisation, shorter training times and the creation of training schemes with less demanding training contents. This call for more flexibility has recently been underlined by the stance of training managers within the Curatorium of the German Economy for Vocational Training in a press release published on 20 November 2003 (see www.kwbberufsbildung.de/frontend.phb3?id=93).

15 In the same way, federal state governments are seeking to improve the portability of qualifications acquired in full-time vocational school courses, such as the abovementioned Baden-Württemberg vocational college (Berufskolleg), by implementing new learning arrangements (eg practice firms) within the curriculum in order to „make schools practical" (Deissinger \& Ruf 2003). 


\section{References}

Arnold, R 1985, 'Das duale System - Ein Modell für den Aufbau leistungsfähiger Berufsbildungssysteme in Entwicklungsländern?', Zeitschrift für internationale erziehungs- und sozialwissenschaftliche Forschung, vol. 2, pp. 343-369.

Avenarius, $\mathrm{H}$ et al. 2003, Bildungsbericht für Deutschland: Erste Befunde (Zusammenfassung) (www.dipf.de/bildungsbericht/bb_zusammenfassung.pdf).

Baethge, M \& Baethge-Kinsky, V 1998, 'Jenseits von Beruf und Beruflichkeit? - Neue Formen von Arbeitsorganisation und Beschäftigung und ihre Bedeutung für eine zentrale Kategorie gesellschaftlicher Integration', Mitteilungen aus der Arbeitsmarkt- und Berufsforschung, vol. 31, pp. 461-472.

Baethge, M 1983, 'Berufsbildungspolitik in den siebziger Jahren: Eine Lektion in ökonomischer Macht und politischer Ohnmacht', in Lipsmeier, A (ed.), Berufsbildungspolitik in den 70er Jahren. Eine kritische Bestandsaufnahme für die 80er Jahre (Beiheft 4 zur Zeitschrift für Berufs- und Wirtschaftspädagogik), Steiner, Wiesbaden, pp. 145-157.

Beicht, U \& Walden, G 2002, 'Wirtschaftlichere Durchführung der Berufsausbildung - Untersuchungsergebnisse zu den Ausbildungskosten der Betriebe', Berufsbildung in Wissenschaft und Praxis, vol. 31, no. 6, pp. 38-43.

Benner, H 1987, 'Arbeiten zur Ordnung der Berufsausbildung vom DATSch bis zum BiBB', in Greinert, W D et al. (eds.), Berufsausbildung und Industrie. Zur Herausbildung industrietypischer Lehrlingsausbildung, Bundesinstitut für Berufsbildung, Berlin, pp. 269-293.

Blankertz, H 1979, 'Zur Geschichte der Berufsausbildung', in Groothoff, H H (ed.), Erziehun gswissenschaftliches Handbuch, Bd. V, Teil 2: Die Handlungs- und Forschungsfelder der Pädagogik (Differentielle Pädagogik), Athenäum, Königstein, pp. 256-285.

Blankertz, H 1982, Die Geschichte der Pädagogik: Von der Aufklärung bis zur Gegenwart, Büchse der Pandora, Wetzlar.

Borch, $\mathrm{H}$ et al. 1991, 'Die neugeordneten industriellen Metall- und Elektroberufe unter dem Aspekt neuer Technologien', in Bonz, B \& Lipsmeier, A (eds.), Computer und Berufsbildung. Beiträge zur Didaktik neuer Technologien in der gewerblichtechnischen Berufsbildung, Holland \& Josenhans, Stuttgart, pp. 139-154.

Brown A \& Evans, K 1994, 'Changing the Training Culture: Lessons from Anglo-German Comparisons of Vocational Education and Training', British Journal of Education and Work, vol. 7, no. 1, pp. 5-15.

Bundesministerium für Arbeit und Sozialordnung \& Bundesministerium für Bildung und Forschung 1999, Eckpunkte für ein Sofortprogramm zum Abbau der Jugendarbeitslosigkeit - Ausbildung, Qualifizierung und Beschäftigung Jugendlicher, BiBB, Berlin.

Burke, G \& Reuling, J (eds.) 2002, Vocational training and lifelong learning in Australia and Germany, NCVER, Adelaide.

Buschfeld, D et al. 1999, Ausbildung von Bürokaufleuten im Rahmen einer Lernortkooperation, FBH/Eusl, Köln. 
Coffey, M \& Rhodes, C 2002, 'Structure and funding of vocational education and training in the United Kingdom, Ireland, France and Germany: an overview', Working paper, Research Centre for Vocational Education and Training, University of Technology, Sydney.

Deissinger, T \& Ruf, M 2003, 'Wissenschaftliche Evaluation des Übungsfirmenkonzepts in Baden-Württemberg - Skizzierung des Forschungsvorhabens', Wirtschaft Plus - Magazin für Wirtschaft und Bildung, no. 1/03, pp. 5-8.

Deissinger, T 1994, 'The Evolution of the Modern Vocational Training Systems in England and Germany: A Comparative View', Compare. A Journal of Comparative Education, vol. 24, no. 1, pp. 17-36.

Deissinger, T 1996, ‘Germany's Vocational Training Act: Its Function as an Instrument of Quality Control within a Tradition-based Vocational Training System', Oxford Review of Education, vol. 22, pp. 317-336.

Deissinger, T 1998, Beruflichkeit als „, organisierendes Prinzip” der deutschen Berufsausbildung, Eusl Verlag, Markt Schwaben.

Deissinger, T 2001a, 'Entwicklung didaktisch-curricularer Vorgaben für die Berufsbildung in Deutschland', in Bonz, B (ed.), Didaktik der beruflichen Bildung, Schneider Verlag, Baltmannsweiler, pp. 71-87.

Deissinger, $\mathrm{T} 2001 \mathrm{~b}$, 'Vocational training in small firms in Germany: the contribution of the craft sector', Education and Training, vol. 43, no. 8/9, pp. 426-436.

Deissinger, T 2001c, 'Zum Problem der historisch-kulturellen Bedingtheit von Berufsbildungssystemen: Gibt es eine „Vorbildfunktion“ des deutschen Dualen Systems im europäischen Kontext?', in Deissinger, T (ed.), Berufliche Bildung zwischen nationaler Tradition und globaler Entwicklung, Nomos, Baden-Baden, pp. 13-44.

Deissinger, T 2001d, 'Zur Frage nach der Bedeutung des Berufsprinzips als „organisierendes Prinzip“ der deutschen Berufsausbildung im europäischen Kontext: Eine deutschfranzösische Vergleichsskizze', Tertium Comparationis, vol. 7., no. 1, pp. 1-18.

Deissinger, T 2002a, 'Chancen und Risiken einer Modularisierung der Berufsausbildung', in Wingens, M \& Sackmann, R (ed.), Bildung und Beruf. Ausbildung und berufsstruktureller Wandel in der Wissensgesellschaft, Juventa, Weinheim, pp. 121137.

Deissinger, T 2002b, 'Different approaches to lifelong learning in Britain and Germany: a comparative view with regard to qualifications and certification frameworks', in Harney, K et al. (eds.), Lifelong learning: one focus, different systems, Peter Lang, Frankfurt, pp. 183-194.

Dostal, W 2002, 'IT-Arbeitsmarkt und erkennbare Qualifikationsstrategien', in Bundesinstitut für Berufsbildung (ed.), Veränderte Arbeitswelt - veränderte Qualifikationen. Wechselwirkungen zwischen Arbeitsmarkt und Bildungsstrukturen, BiBB, Bonn, pp. 141-157.

Ertl, H 2000, 'The Enduring Nature of the Tripartite System of Secondary Schooling in Germany: some explanations', British Journal of Educational Studies, vol. 48, no. 4, p. 391-428. 
Euler, D 1998, Modernisierung des dualen Systems - Problembereiche, Reformvorschläge, Konsens- und Dissenslinien (Materialien zur Bildungsplanung und zur Forschungsförderung), BLK, Bonn.

Euler, D 2000, 'Bekannt, aber nicht anerkannt - zur Weiterentwicklung der Berufsausbildung in schulischer Trägerschaft', in Zimmer, G (ed.), Zukunft der Berufsausbildung. Zweite Modernisierung unter Beteiligung der beruflichen Vollzeitschulen, W. Bertelsmann, Bielefeld, pp. 71-88.

European Commission 1993, White Paper on Growth, Competitiveness and Employment: The Challenges and Ways forward into the 21 st Century (December 1993), European Commission, Brussels.

European Commission 1995, White Paper on Education and Training: Teaching and Learning - Towards the Learning Society (November 1995), European Commission, Brussels.

Federal Ministry of Education and Research 2003, Report on Vocational Education and Training for the Year 2003, Part I (www.bmbf.de/pub/bbb2003_en.pdf).

Feller, G 2000, 'Ausbildung an Berufsfachschulen - Ein differenziertes und flexibles Qualifikationssystem', in Kaiser, F J (ed.), Berufliche Bildung in Deutschland für das 21. Jahrhundert, Bundesanstalt für Arbeit, Nürnberg, pp. 439-450.

Géhin, J P \& Méhaut, P 1995, 'The German Dual System: A Model for Europe?', Industrielle Beziehungen, vol. 2, no. 1, pp. 64-81.

Geissler, K A 1991, 'Das Duale System der industriellen Berufsausbildung hat keine Zukunft', Leviathan. Zeitschrift für Sozialwissenschaft, vol. 19, pp. 68-77.

Gonon, P 2001, 'Neue Reformbestrebungen im beruflichen Bildungswesen in der Schweiz', in Deissinger, T (ed.) Berufliche Bildung zwischen nationaler Tradition und globaler Entwicklung, Nomos, Baden-Baden, pp. 63-77.

Greinert, W D 1994, „The German System” of Vocational Training. History, Organization, Prospects, Nomos Verlag, Baden-Baden.

Greinert, W D 2001, 'Die Übertragbarkeit des Dualen Systems in Entwicklungsländer: Möglichkeiten und Begrenzungen einer politischen Strategie', in Deissinger, T (ed.), Berufliche Bildung zwischen nationaler Tradition und globaler Entwicklung, Nomos, Baden-Baden, pp. 45-60.

Gruber, E 2001, 'Entwicklungen der Berufsbildung in Österreich', in Deissinger, T (ed.), Berufliche Bildung zwischen nationaler Tradition und globaler Entwicklung, Nomos, Baden-Baden, pp. 79-101.

Harney, K 1985, 'Der Beruf als Umwelt des Betriebs. Vergleichende, historische und systematische Aspekte einer Differenz', in Verbände der Lehrer an beruflichen Schulen in Nordrhein-Westfalen (eds.), Die Relevanz neuer Technologien für die Berufsausbildung. Krefeld, pp. 118-130.

Higginson, J H 1990, 'Michael Sadler and the German Connection', Oxford Review of Education, vol. 16, pp. 245-253.

Hodgson, A \& Spours, K 1997, 'Modularization and the 14-19 Qualifications System', in Hodgson, A \& Spours, K (eds.), Dearing and Beyond. Qualifications, Frameworks and Systems, Kogan Page, London, pp. 105-120. 
Keating, J et al. 2002, Comparative study of vocational education and training systems: national vocational education and training systems across three regions under pressure of change, NCVER, Adelaide.

Kell, A 1996, 'Berufliche Schulen in der Spannung von Bildung und Beruf', Zeitschrift für Berufs- und Wirtschaftspädagogik, vol. 92, pp. 6-18.

Kell, A 1999, 'Berufsbildung zwischen privaten Interessen und gesellschaftlicher Verantwortung', in Tramm, T et al. (eds.), Professionalisierung kaufmännischer Berufsbildung. Festschrift für Frank Achtenhagen, Peter Lang, Frankfurt, pp. 85-105.

Kell, A 2001, 'Berufsbildungsreformen um 1970 aus berufs- und wirtschaftspädagogischer Sicht', in Lisop, I (ed.), Vom Handlungsgehilfen zur Managerin. Ein Jahrhundert der kaufmännischen Professionalisierung in Wissenschaft und Praxis am Beispiel Frankfurt am Main, G.A.F.B. Verlag, Frankfurt, pp. 181-200.

Klein, H J 1989, 'Die Neuordnung der industriellen Metall- sowie der handwerklichen Elektroberufe unter besonderer Berücksichtigung der neuen Technologien', Erziehungswissenschaft und Beruf, vol. 37, pp. 98-104.

Knörr, M 1996, Die Berufszulassung zum Handwerk seit dem Ende des Alten Reiches. Dissertation, Nürnberg.

Miller Idriss, C 2002, 'Challenge and Change in the German Vocational System since 1990', Oxford Review of Education, vol. 28, no. 4, pp. 473-490.

Misko, J 1999, Competency-based Training, NCVER, Adelaide.

Müller, K, Häussler, J \& Sonnek, W 1997, Die neuen Ausbildungsberufe der Informationsund Telekommunkationstechnik (IT-Berufe), Deutscher Instituts-Verlag, Köln.

Muth, W 1985, Berufsausbildung in der Weimarer Republik, Franz Steiner, Stuttgart.

National Centre for Vocational Education Research 2001, Australian apprenticeships. facts, fiction and future, NCVER, Adelaide.

OECD 2000, Measuring student knowledge and skills. The PISA 2000 assessment of reading, mathematical and scientific literacy, OECD, Paris.

OECD 2003, Education at a Glance, OECD, Paris.

Pahl, J P \& Rach, G 1999, 'Zusatzqualifikationen - Wegbereiter zur Dynamisierung der Berufsbildung', Die berufsbildende Schule, vol. 51, no. 10, pp. 356-361.

Pätzold, G 1990, 'Neue Ausbildungsberufe, berufliche Handlungskompetenz, didaktisches Handeln und Lernortkooperation', in Pätzold, G (ed.), Lernortkooperation: Impulse für die Zusammenarbeit in der beruflichen Bildung, Sauer, Heidelberg, pp. 159-180.

Petersen, A W \& Wehmeyer, C 2000, 'Die neuen IT-Berufe auf dem Prüfstand. Erste Ergebnisse der bundesweiten IT-Studie', Berufsbildung in Wissenschaft und Praxis, vol. 29 , no. 6 , pp. 13-18.

Phillips, D 1995, 'Lessons from Germany? The Case of German Secondary Schools', in Phillips, D (ed.), Education in Germany. Tradition and Reform in Historical Context, Routledge, London, pp. 60-79.

Pilz, M 1999, Modulare Strukturen in der beruflichen Bildung - eine Alternative für Deutschland? Eine explorative Studie am Beispiel des schottischen Modulsystems, Eusl, Markt Schwaben. 
Raggatt, P 1988, 'Quality Control in the Dual System of West Germany', Oxford Review of Education, vol. 14, no. 2, pp. 163-186.

Reinberg, A \& Hummel, M 2001, 'Die Entwicklung im deutschen Bildungssystem vor dem Hintergrund des qualifikatorischen Strukturwandels auf dem Arbeitsmarkt', in Reinberg, A (ed.), Arbeitsmarktrelevante Aspekte der Bildungspolitik, Bundesanstalt für Arbeit, Nürnberg, pp. 1-62.

Reinisch, H 1993, 'Was ist neu an der Neuordnung der Büroberufe? - Einschätzungen aus wirtschaftspädagogischer Sicht', Zeitschrift für Berufs- und Wirtschaftspädagogik, vol. 89, pp. 134-148.

Reinisch, H 2001, 'Formen und Funktionen beruflicher Vollzeitschulen in Deutschland - aufgezeigt am Beispiel des Bundeslandes Niedersachsen', in Frommberger, D, Reinisch, H \& Santema, M (eds.), Berufliche Bildung zwischen Schule und Betrieb. Stand und Entwicklung in den Niederlanden und Deutschland, Eusl, Markt Schwaben, pp. 11-65.

Ryan, P 2001, 'Apprenticeship in Britain - tradition and innovation', in Deissinger, T (ed.), Berufliche Bildung zwischen nationaler Tradition und globaler Entwicklung, Nomos, Baden-Baden, pp. 133-157.

Sander, M 1998, 'Lernen im Kundenauftrag - zur Bestimmung von Aufgaben zwischen Betrieb und Schule', in Patt, D, Gerwin, W \& Hoppe, M (eds.), Kooperieren und Qualifizieren im Handwerk (Berichte zur beruflichen Bildung, H. 222), W. Bertelsmann, Bielefeld, pp. 75-94.

Schelten, A 1991, Einführung in die Berufspädagogik, Franz Steiner, Stuttgart.

Schütte, F 1992, Berufserziehung zwischen Revolution und Nationalsozialismus. Ein Beitrag zur Bildungs- und Sozialgeschichte der Weimarer Republik, Deutscher Studien Verlag, Weinheim.

Sloane, P F E 1997, 'Modularisierung in der beruflichen Ausbildung - oder: Die Suche nach dem Ganzen', in Euler, D \& Sloane, P F E (eds.), Duales System im Umbruch. Eine Bestandsaufnahme der Modernisierungsdebatte, Eusl, Pfaffenweiler, pp. 223-245.

Steeger, G 1999, Zukünftiger Weiterbildungsbedarf im Handwerk, FBH/Eusl, Köln.

Stiller, I 1992, 'Zur Entwicklung der kaufmännischen und verwaltenden Ausbildungsberufe', in Bundesinstitut für Berufsbildung (ed.), Innovationen in der beruflichen Bildung. Hermann Schmitt zum 60. Geburtstag, Bundesinstitut für Berufsbildung, Berlin, pp. 327-345.

Wolf, A 1995 Competence-based Assessment, Open University Press, Buckingham.

Zabeck, J 1975a, 'Allgemeinbildung und Berufsbildung. Über den Widersinn der Restauration eines Gegensatzes mit der Absicht, ihn zu überwinden', in Schanz, H (ed.), Grundfragen der Berufsbildung, Holland und Josenhans, Stuttgart, pp. 41-56.

Zabeck, J 1975b, Die Bedeutung des Selbstverwaltungsprinzips für die Effizienz der betrieblichen Ausbildung. Untersuchung im Auftrage des Ministers für Wirtschaft, Mittelstand und Verkehr des Landes Nordrhein-Westfalen, Mannheim.

Zedler, R 2002, 'Industrielle Metall- und industrielle Elektro-Ausbildungsberufe: Neugestaltung kommt in Gang', Wirtschaft und Berufserziehung, vol. 54, no. 4, pp. 13-14. 